\title{
Leren in de Zorg \& Welzijn
}

Citation for published version (APA):

Fouarge, D. (2016). Leren in de Zorg \& Welzijn. ROA. ROA Fact Sheets No. 004 https://doi.org/10.26481/umarof.2016004

Document status and date:

Published: 01/01/2016

DOI:

10.26481/umarof.2016004

Document Version:

Publisher's PDF, also known as Version of record

\section{Please check the document version of this publication:}

- A submitted manuscript is the version of the article upon submission and before peer-review. There can be important differences between the submitted version and the official published version of record.

People interested in the research are advised to contact the author for the final version of the publication, or visit the DOI to the publisher's website.

- The final author version and the galley proof are versions of the publication after peer review.

- The final published version features the final layout of the paper including the volume, issue and page numbers.

Link to publication

\footnotetext{
General rights rights.

- You may freely distribute the URL identifying the publication in the public portal. please follow below link for the End User Agreement:

www.umlib.nl/taverne-license

Take down policy

If you believe that this document breaches copyright please contact us at:

repository@maastrichtuniversity.nl

providing details and we will investigate your claim.
}

Copyright and moral rights for the publications made accessible in the public portal are retained by the authors and/or other copyright owners and it is a condition of accessing publications that users recognise and abide by the legal requirements associated with these

- Users may download and print one copy of any publication from the public portal for the purpose of private study or research.

- You may not further distribute the material or use it for any profit-making activity or commercial gain

If the publication is distributed under the terms of Article $25 \mathrm{fa}$ of the Dutch Copyright Act, indicated by the "Taverne" license above, 
Maastricht University Lemding in Lanning!

Over de data:

Het ROA brengt het formele en informele leren in kaart aan de hand van de ROA Levenslang Leren Enquête (ROA LLL).

2. De enquête is gehouden onder een representatieve steekproef van de Nederlandse beroepsbevolking.

toe zijn data beschikbaar voor de jaren 2004, 2007, 2010 en 2013. In 2017 volgt een nieuwe peiling.

De data over zorg en welzijn heeft betrekking op alle werkenden in de sector, ongeacht functie.
Research Centre for Education and the Labour Market | ROA

\section{Leren in de Zorg \& Welzijn}

\section{ROA Fact Sheet}

\section{Postbus 616}

6200 MD Maastrich

$\mathrm{T}+31433883647$

$\mathrm{F}+31433884914$

secretary-roa-sbe@maastrichtuniversity.

www.roa.n

Maastricht University

school of Business and Economic
ROA-F-2016/4

Researchcentrum voor Onderwijs en Arbeidsmarkt | ROA Research Centre For Education and the Labour Market / ROA 


\begin{tabular}{|c|c|c|}
\hline Dynamiek op de arbeidsmarkt & Competentieveroudering & Later met pensioen \\
\hline 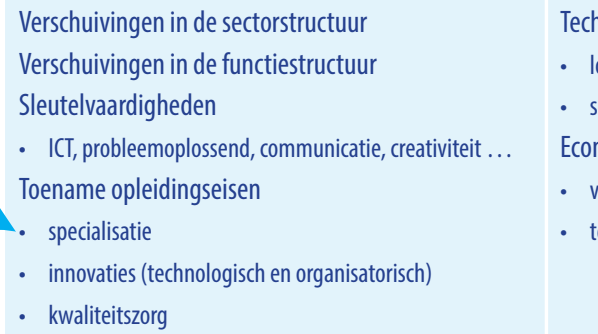 & 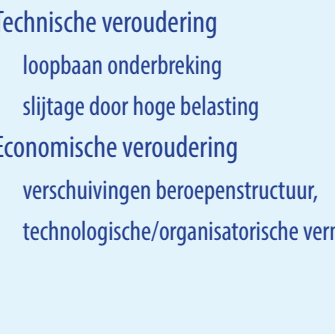 & $\begin{array}{l}\text { Prikkels om langer door te werken } \\
\text { · pensioenleettidi: } 61 \text { jari in } 200 ; \text {; } 64 \text { jarar en } 5 \text { manden } \\
\text { in } 2015 \\
\text { Langer inzetbaar blijiven }\end{array}$ \\
\hline $\begin{array}{l}\text { In Nederland is in de afgelopen } 20 \text { jaar het opleidingsniveau } \\
\text { in beroepen met bijna } 1 \text { opleidingsjar toegenomen, } \\
\text { voornamelijk als gevolg van toegenomen opleidingseisen } \\
\text { binnen beroepen. }\end{array}$ & & $\begin{array}{l}\text { Ierkenden in de zorg en welzijin rapporteren vaker dan } \\
\text { andere sectoren dat er sprake is van organisatorische } \\
\text { twwikkelingen die de inhoud van het werk veranderen. Ze } \\
\text { nzich minder bewust van technologische ontwikkelingen } \\
\text { e de inhoud van het werk veranderen. }\end{array}$ \\
\hline
\end{tabular}

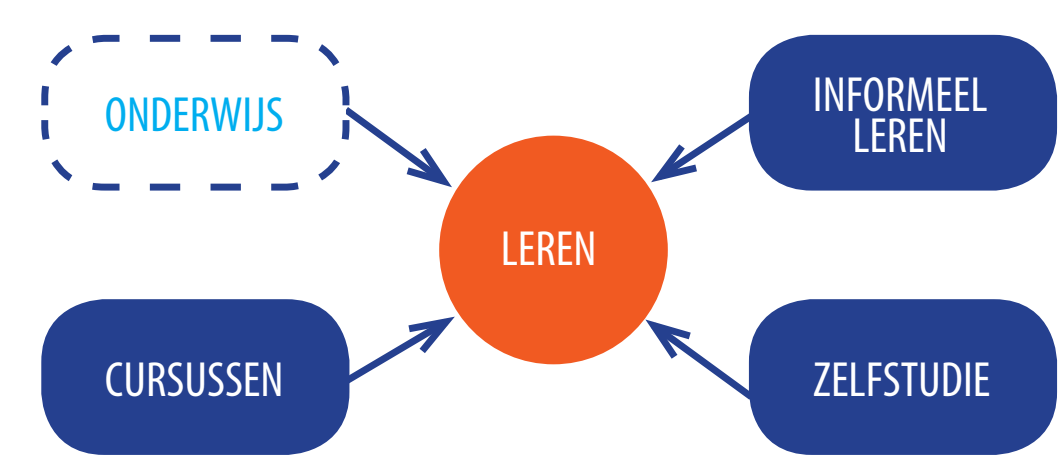

Deelname aan cursussen en trainingen in afgelopen 2 jar

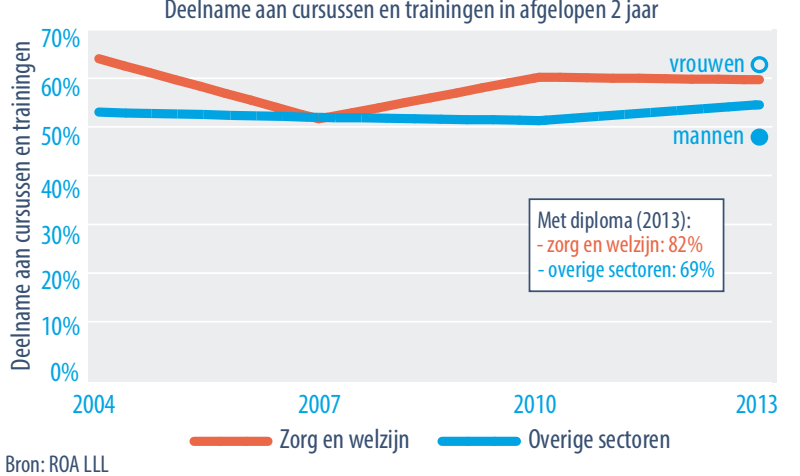

Werkenden in de zorg en welzijn volgen vaker cursussen en trainingen dan in andere sectoren.

- De cursusdeelname was in 2013 hoger onder vrouwen (63\%) dan onder mannen (48\%).

- De gemiddelde cursusduur in de zorg en welzijn was in 201316 uur, iets korter dan in andere sectoren (20 uur).

- In de zorg sluit $82 \%$ de cursus a met een diploma. Dat is meer dan in andere sectoren (69\%).

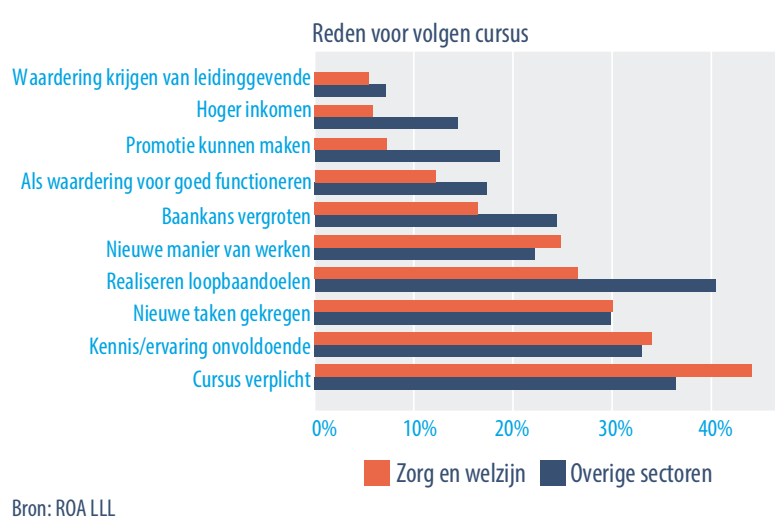

Cursus vaak gericht op:

Vaktechnische competenties

Omgaan met mensen

-

- Vaker verplicht

- Vaker gericht op nieuwe manieren van werken

- Meer stimuleren dat wat men leert in de praktijk wordt gebracht

Rol voor leidinggevende en collega's $\rightarrow$ bevorderen leerklimaat

Bron: KOALLLE

Zorg en welzijn $\mathbf{0}$ Overige sectoren

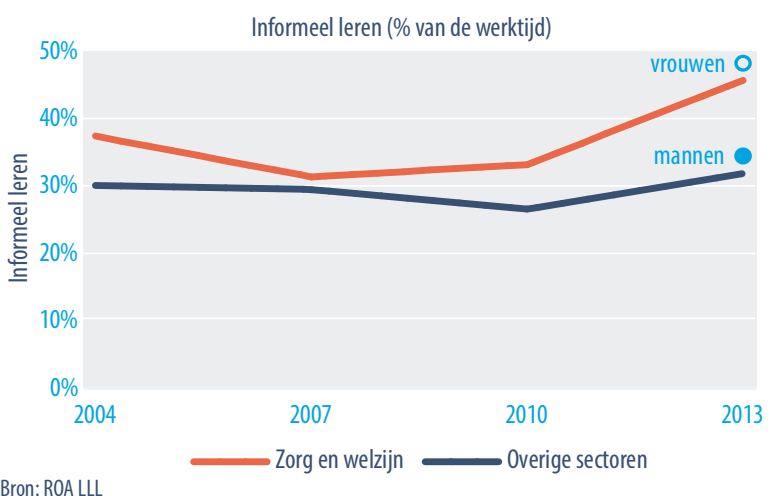

- Leren doe je niet alleen tijdens een cursus of training. In de zorg en welzijn besteden $46 \%$ van de werktijd aan taken waarvan zij kunnen leren (informeel leren). Dat is meer dan in andere sectoren. - Vrouwen doen meer aan informeel leren dan manen.

Bron:RoALLL

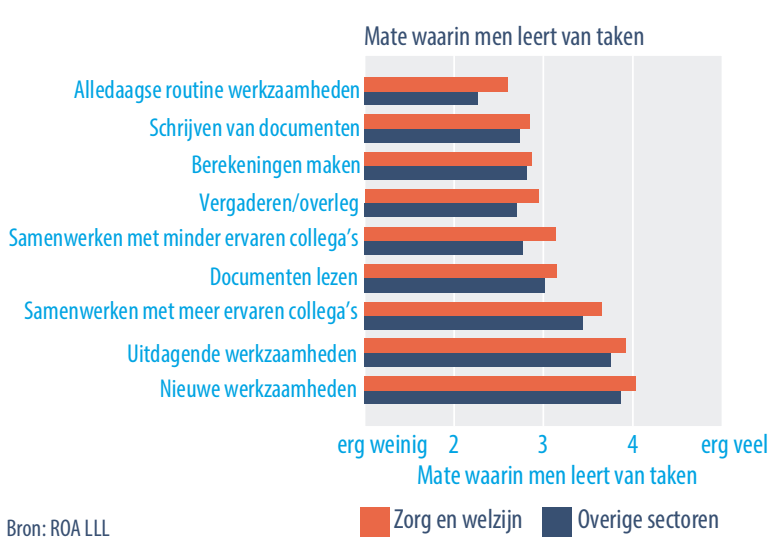

De taken die men doet bepalen in welke mate men leert tijdens het werk. Taken waar men veel informeel leer:

Uitvoeren van nieuwe werkzaamheden

Uitvoeren van vitdagende werkzaamheden
Zorg en welzijn overige sectoren
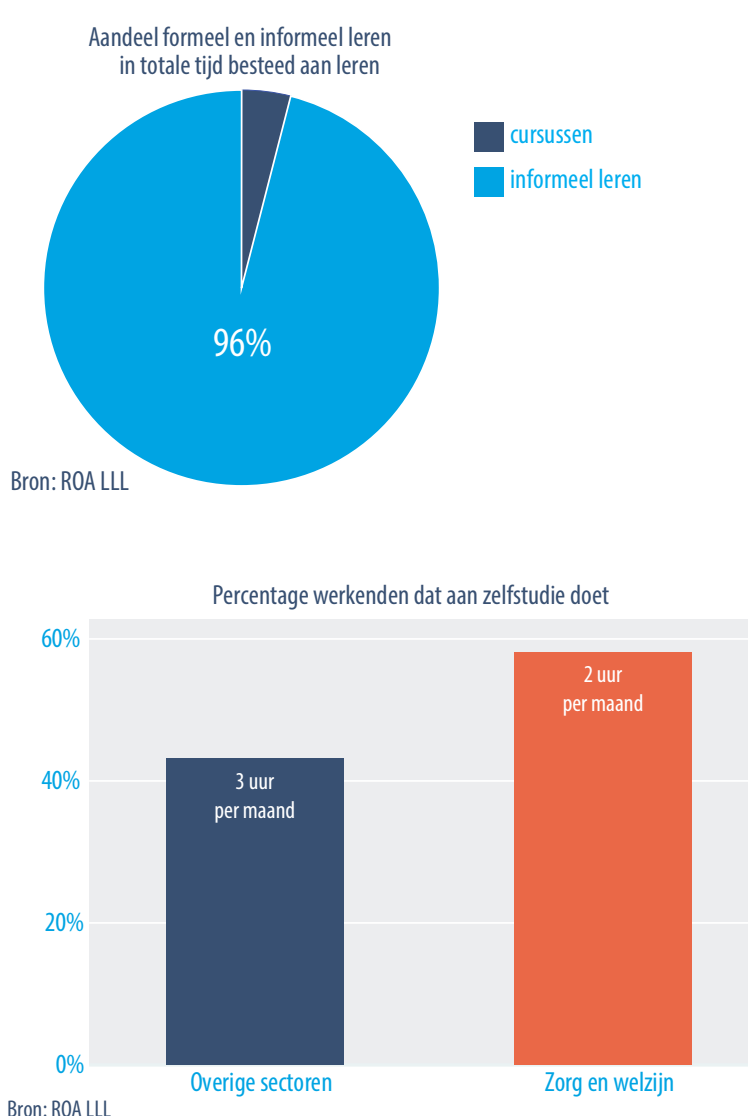

Van alle tijd die men besteed aan leren, heeft $96 \%$ betrekking op informeel leren

- Informeel leren is net zo een effectieve manier van leren als de deelname aan cursussen: Men leert evenveel van een cursus van 8 uur als van 8 uur informeel leren.

- Bijna $60 \%$ van de werkenden in de zorg en welzijn doet aan zelfstudie. - Dat is meer dan in andere sectoren, maar men besteed minder tijd aan zelstudie (2 uur per maand) dan in andere sectoren (3 uur per maand. 